\title{
Short-term ionic plasticity at GABAergic synapses
}

\author{
Joseph V. Raimondo ${ }^{1}$, Henry Markram ${ }^{2}$ and Colin J. Akerman ${ }^{1 *}$ \\ 'Akerman Lab, Department of Pharmacology, Oxford University, Oxford, Oxfordshire, UK \\ ${ }^{2}$ Blue Brain Project, Brain Mind Institute, Ecole Polytechnique Fédérale de Lausanne, Lausanne, Switzerland
}

\section{Edited by:}

Karri P. Lamsa, University of Oxford, UK

\section{Reviewed by:}

Melanie A. Woodin, University of

Toronto, Canada

Kai Kaila, University of Helsinki,

Finland

\section{*Correspondence:}

Colin J. Akerman, Akerman Lab,

Department of Pharmacology,

Oxford University, Oxford, Mansfield

Road, OX1 30T, USA.

e-mail: colin.akerman@pharm.

ox.ac.uk
Fast synaptic inhibition in the brain is mediated by the pre-synaptic release of the neurotransmitter $\gamma$-Aminobutyric acid (GABA) and the post-synaptic activation of GABA-sensitive ionotropic receptors. As with excitatory synapses, it is being increasinly appreciated that a variety of plastic processes occur at inhibitory synapses, which operate over a range of timescales. Here we examine a form of activity-dependent plasticity that is somewhat unique to GABAergic transmission. This involves short-lasting changes to the ionic driving force for the post-synaptic receptors, a process referred to as short-term ionic plasticity. These changes are directly related to the history of activity at inhibitory synapses and are influenced by a variety of factors including the location of the synapse and the post-synaptic cell's ion regulation mechanisms. We explore the processes underlying this form of plasticity, when and where it can occur, and how it is likely to impact network activity.

Keywords: short-term ionic plasticity, GABA, chloride, GABA $A_{A}$ receptors, synaptic transmission, EGABA, reversal potential, $\mathrm{pH}$

\section{INTRODUCTION}

Synaptic plasticity refers to structural and functional changes that occur at synapses in response to particular stimuli or patterns of activity. These processes can operate over a range of timescales, from short-term modification of synaptic transmission occurring over tens of milliseconds, to long-lasting changes that persist for hours and more. The changes that result are thought to contribute to phenomena as important and diverse as synaptic integration, the flow of information through neuronal circuits, learning and memory, neural circuit development and disease states such as epilepsy. In conjunction with the extensive research on plasticity at excitatory glutamatergic synapses, plastic processes at inhibitory synapses have received increasing attention over the past two decades. This reflects a growing appreciation of how fluctuations in the strength of inhibitory synapses also shape the input-output relationship of neurons and the computations of neuronal networks. This review focuses upon short-lasting changes in the strength of inhibitory synapses. Short-term plasticity has classically been linked to changes in vesicular release probability or mechanisms that alter post-synaptic conductance, such as receptor desensitization. In addition to these processes, inhibitory synapses exhibit a form of short-term plasticity that involves changes in the ionic driving force for post-synaptic ionotropic receptors. This process is the short-term variety of what has previously been referred to as ionic plasticity (Rivera et al., 2005; Blaesse et al., 2009) or ionic shift plasticity (Lamsa et al., 2010). Type A ionotropic $\gamma$-Aminobutyric acid receptors $\left(\mathrm{GABA}_{\mathrm{A}} \mathrm{Rs}\right)$ are the primary mediators of fast synaptic inhibition in the brain and the reversal potential for these receptors $\left(E_{\mathrm{GABA}}\right)$ is typically close to the neuronal resting membrane potential. This means that relatively small changes to $E_{\mathrm{GABA}}$ can vary the functional effect of $\mathrm{GABA}_{\mathrm{A}} \mathrm{R}$ activation and consequently neuronal output. Here we explore how short-term, activity-dependent changes in the driving force for $\mathrm{GABA}_{\mathrm{A}}$ Rs occur and how they might affect ongoing physiological and pathological network activity.

\section{GABA $_{A}$ RECEPTOR MEDIATED SYNAPTIC TRANSMISSION AND PLASTICITY}

Two principle variables determine the effect of $\mathrm{GABA}_{\mathrm{A}} \mathrm{R}$ mediated synaptic transmission on the post-synaptic membrane potential. The first is $E_{\mathrm{GABA}}$ and the second is the $\mathrm{GABA}_{\mathrm{A}} \mathrm{R}$ conductance ( $g \mathrm{GABA}$ ). Open $\mathrm{GABA}_{\mathrm{A}}$ Rs are approximately four times more permeable to chloride $\left(\mathrm{Cl}^{-}\right)$than to bicarbonate $\left(\mathrm{HCO}_{3}^{-}\right)$ions (Kaila and Voipio, 1987; Kaila et al., 1989). Therefore at rest, $E_{\mathrm{GABA}}$ (typically $-75 \mathrm{mV}$ ) is much closer to the very negative $\mathrm{Cl}^{-}$reversal $\left(E_{\mathrm{Cl}^{-}}\right.$; typically $\left.-85 \mathrm{mV}\right)$ than the considerably more positive $\mathrm{HCO}_{3}^{-}$reversal $\left(E_{\mathrm{HCO}_{3}^{-}}\right.$; typically $-20 \mathrm{mV}$ ) (Kaila et al., 1993; Lambert and Grover, 1995). When GABA binds to $\mathrm{GABA}_{\mathrm{A}}$ Rs, the bulk of anion flux through the channel is $\mathrm{Cl}^{-}$flowing down its electrochemical gradient from outside to inside the cell. This causes the membrane potential hyperpolarization typical of classic $\mathrm{GABA}_{\mathrm{A}} \mathrm{R}$ mediated inhibition. However, if $E_{\mathrm{Cl}^{-}}$is positive of the resting membrane potential, $\mathrm{GABA}_{\mathrm{A}} \mathrm{R}$ activation will result in $\mathrm{Cl}^{-}$efflux and depolarization. This can still have an inhibitory influence due to the shunting effect upon the membrane, and particularly if $E_{\mathrm{Cl}^{-}}$and $E_{\mathrm{GABA}}$ remain more negative than the action potential threshold (Kaila, 1994; Farrant and Kaila, 2007). If $E_{\mathrm{Cl}^{-}}$exceeds the action potential threshold, $\mathrm{GABA}_{\mathrm{A}} \mathrm{R}$ mediated transmission is likely to increase the probability of action potential generation and will therefore exert an excitatory effect. In this manner the intracellular $\mathrm{Cl}^{-}$concentration $\left[\mathrm{Cl}^{-}\right]_{\mathrm{i}}$, by setting $E_{\mathrm{Cl}^{-}}$and $E_{\mathrm{GABA}}$, determines the "mode" of $\mathrm{GABA}_{\mathrm{A}} \mathrm{R}$ operation. The extent to which GABAergic inputs can move a neuron's membrane potential toward $E_{\mathrm{GABA}}$ is a function of $g \mathrm{GABA}$. $g \mathrm{GABA}$ in turn 
is determined by a host of synaptic parameters including the amount of transmitter released, the number of $\mathrm{GABA}_{\mathrm{A}}$ Rs present, the $\mathrm{GABA}_{\mathrm{A}} \mathrm{R}$ subunit composition, channel kinetics, phosphorylation state and presence of channel modulators. Whereas $E_{\mathrm{GABA}}$ sets the "mode," gGABA can be thought of as determining the "strength" of the GABAergic synapse.

Changes to either $g \mathrm{GABA}$ or $E_{\mathrm{GABA}}$ are known to underlie long-term plasticity at GABAergic synapses (Gaiarsa et al., 2002; Wright et al., 2011). These sustained changes to GABAergic transmission have been demonstrated in numerous brain regions, species type and experimental preparations, and can be generated by periods of either pathological or physiological activity (Cohen et al., 2002; Woodin et al., 2003; Fiumelli et al., 2005; Pathak et al., 2007). In addition to long-term changes in GABAergic synaptic function, it is known that post-synaptic responses can also vary on short time scales, as a function of recent presynaptic activity (Davies et al., 1990; Fleidervish and Gutnick, 1995; Gupta et al., 2000). Repeated activation at some synapses can result in enhanced transmission (facilitation), while at other synapses repeated use results in a transient decrease in transmission (depression). In reality, multiple short-term plasticity mechanisms are likely to co-occur at synapses and the resulting behavior will be a combination of facilitation and depression that depends on the timing of synaptic activation (Tsodyks and Markram, 1997; Varela et al., 1997). Indeed, GABAergic synapses are known to display an array of short-term plasticity phenomena (Davies et al., 1990; Fleidervish and Gutnick, 1995; Jiang et al., 2000; Kirischuk et al., 2002; Mott et al., 1993), and in some cases have been related to the specific interneuron type that is the pre-synaptic source (Gupta et al., 2000; Pouille and Scanziani, 2004). Short-term plasticity phenomena such as these are generally understood to relate pre-dominantly to pre-synaptic processes. For instance, synaptic facilitation is typically attributed to residual elevations of pre-synaptic calcium $\left(\mathrm{Ca}^{2+}\right)$, whilst synaptic depression is linked either to depletion of readily releasable synaptic vesicles (Zucker and Regehr, 2002) or the activation of

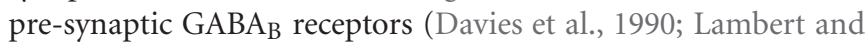
Wilson, 1994). However, post-synaptic mechanisms can also contribute to short-term synaptic plasticity at GABAergic synapses and these include desensitization of the post-synaptic receptors (McCarren and Alger, 1985; Overstreet et al., 2000) or changes in the ionic driving force for the post-synaptic receptors. This latter process - transient shifts in the ionic driving force of the postsynaptic $\mathrm{GABA}_{\mathrm{A}} \mathrm{Rs}$ - will form the focus of the remainder of this review.

\section{THE BASIC MECHANISM UNDERLYING SHORT-TERM IONIC PLASTICITY AT GABAergic SYNAPSES}

Short-term changes to receptor reversal potentials via breakdown of ionic concentration gradients are not thought to occur at glutamatergic synapses. This is because the major ionotropic receptors for glutamate, AMPA, NMDA, and Kainate receptors, are equally permeable to $\mathrm{Na}^{+}$and $\mathrm{K}^{+}$. The concentration gradients across the neuronal membrane for these two ions are diametrically opposed, resulting in a reversal potential for glutamate receptors of approximately $0 \mathrm{mV}$. During periods of intense glutamatergic synaptic activity, sodium influx and potassium efflux may reduce their respective local concentration gradients, but as both ion concentrations are perturbed to a similar extent, this will have a minimal effect on the combined reversal potential for glutamate receptors.

The situation within the GABAergic system is quite different. As described above, the major ionotropic receptor for GABA, the $\mathrm{GABA}_{\mathrm{A}} \mathrm{R}$, is permeable primarily to $\mathrm{Cl}^{-}$and to a lesser extent $\mathrm{HCO}_{3}^{-}$(Kaila and Voipio, 1987; Kaila et al., 1989). Therefore at rest, $E_{\mathrm{GABA}}$ (typically $-75 \mathrm{mV}$ ) is considerably closer to the very negative $\mathrm{Cl}^{-}$reversal $\left(E_{\mathrm{Cl}^{-}}\right.$; typically $\left.-85 \mathrm{mV}\right)$ than the more positive $\mathrm{HCO}_{3}^{-}$reversal $\left(E_{\mathrm{HCO}_{3}^{-}}\right.$; typically $-20 \mathrm{mV}$ ) (Kaila et al., 1993; Lambert and Grover, 1995). During intense activation of $\mathrm{GABA}_{\mathrm{A}} \mathrm{Rs}$ however, rapid $\mathrm{Cl}^{-}$influx can exceed $\mathrm{Cl}^{-}$extrusion mechanisms and a reduction in the transmembrane $\mathrm{Cl}^{-}$gradient occurs (Kaila and Voipio, 1987; Kaila et al., 1989; Staley et al., 1995; Staley and Proctor, 1999). It is thought that a corresponding collapse of the $\mathrm{HCO}_{3}^{-}$gradient is prevented by the activity of intra- and extra-cellular carbonic anhydrases, which use $\mathrm{CO}_{2}$ as a substrate to rapidly regenerate intracellular $\mathrm{HCO}_{3}^{-}$ (Kaila et al., 1990; Rivera et al., 2005). As a result, the intracellular $\mathrm{Cl}^{-}$accumulation that occurs during repeated activation of $\mathrm{GABA}_{\mathrm{A}}$ Rs means that $E_{\mathrm{Cl}^{-}}$and hence $E_{\mathrm{GABA}}$ shift toward the more positive $E_{\mathrm{HCO}_{3}^{-}}$(Figure 1). Such a process is thought to contribute to short-term synaptic depression of GABAergic potentials (McCarren and Alger, 1985; Huguenard and Alger, 1986).

This process does not only reduce the size of inhibitory postsynaptic potentials (IPSPs), but strong $\mathrm{GABA}_{\mathrm{A}} \mathrm{R}$ activation may cause IPSPs to change from being hyperpolarizing to depolarizing, as $E_{\mathrm{GABA}}$ shifts in a positive direction (Figure 1). Such biphasic responses have been widely documented (Alger and Nicoll, 1979; Andersen et al., 1980; Thompson and Gahwiler, 1989a,b). As described above, the most accepted explanation for this phenomenon is the differential collapse of the opposing concentration gradients of $\mathrm{Cl}^{-}$and $\mathrm{HCO}_{3}^{-}$(Kaila et al., 1989; Staley et al., 1995; Staley and Proctor, 1999), although some contradictory observations remain unexplained (Perkins and Wong, 1997; Perkins, 1999). The magnitude of the late phase of the biphasic response is accentuated by extracellular potassium accumulation which further serves to depolarize the cell membrane (Kaila et al., 1997; Smirnov et al., 1999; Voipio and Kaila, 2000). This is thought to occur via the activity of the electroneutral $\mathrm{K}^{+}-\mathrm{Cl}^{-}$ co-transporter KCC2, which leads to the accelerated extrusion of both $\mathrm{Cl}^{-}$and $\mathrm{K}^{+}$in response to the $\mathrm{GABA}_{\mathrm{A}} \mathrm{R}$-mediated accumulation of intracellular $\mathrm{Cl}^{-}$(Viitanen et al., 2010). It should be remembered that such shifts in $E_{\mathrm{GABA}}$ are expected to be temporary, which is why this phenomenon can be thought of as a short-term plastic change. Once $\mathrm{GABA}_{\mathrm{A}} \mathrm{R}$ activity subsides, transporter proteins will return $\left[\mathrm{Cl}^{-}\right]_{\mathrm{i}}$ to resting levels on a timescale of seconds or minutes, depending upon the size of the $E_{\mathrm{GABA}}$ shift (Staley and Proctor, 1999; Raimondo et al., 2012a).

\section{FACTORS THAT INFLUENCE IONIC PLASTICITY AT GABAergic SYNAPSES}

Any factor that affects the rate of $\mathrm{Cl}^{-}$accumulation during $\mathrm{GABA}_{\mathrm{A}} \mathrm{R}$ activation will influence how rapidly and by how much 


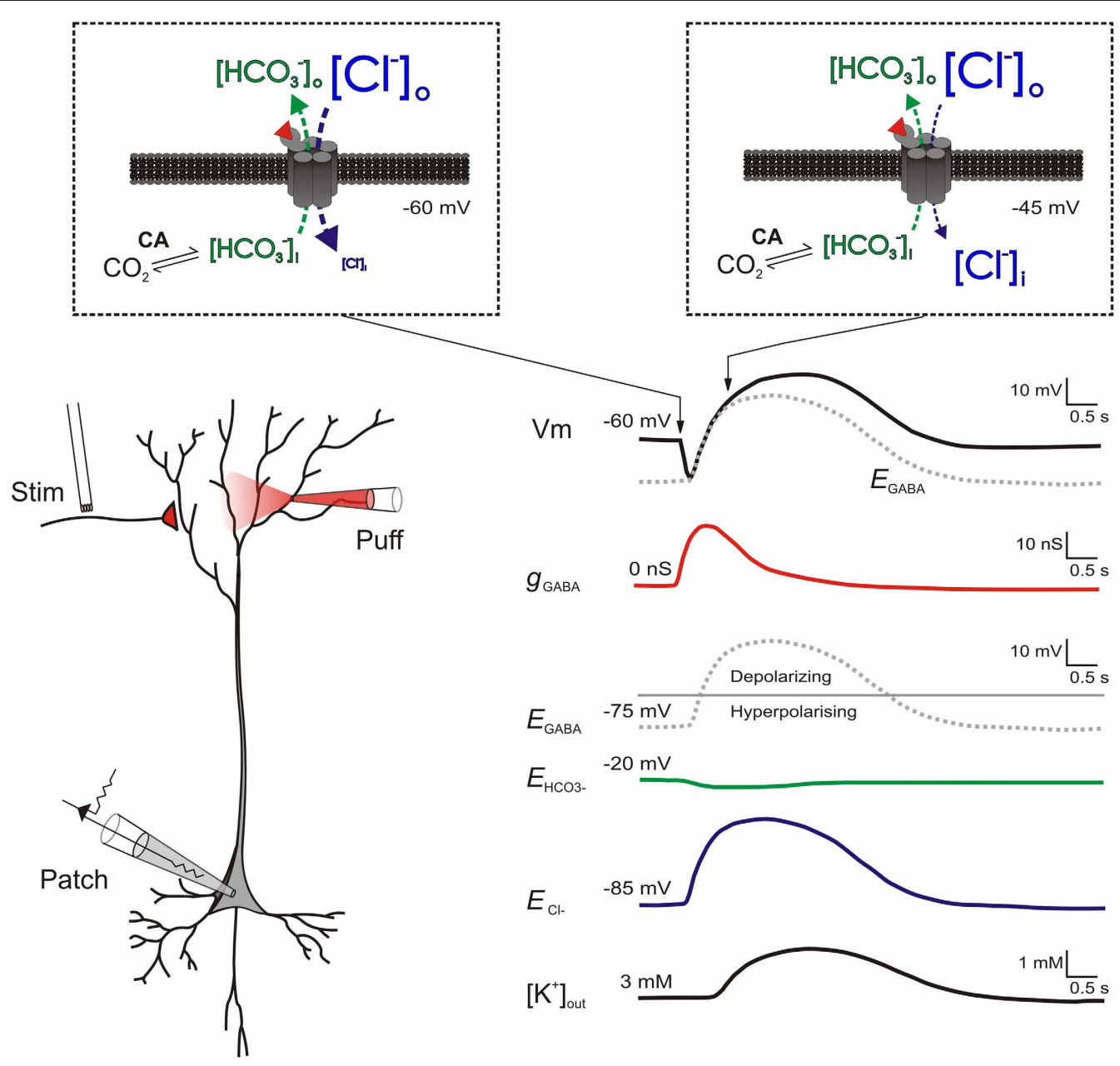

FIGURE 1 | Biphasic responses to intense $\mathrm{GABA}_{A} R$ activation are caused by a rapid shift from hyperpolarizing to depolarizing $E_{\mathrm{GABA}}$. (Left) a schematic of a patched pyramidal neuron receiving strong $G A B A_{A} R$ input either via stimulation of GABAergic afferents or application of GABA. (Right) traces showing the putative changes in ionic and synaptic parameters as a result of the $G A B A_{A} R$ activation. Separate traces show the cell's membrane potential $\left(V m\right.$, black); the $\mathrm{GABA}_{A} R$ conductance ( $\mathrm{g}_{\mathrm{GABA}}$, red), the reversal potentials for the $\mathrm{GABA}_{\mathrm{A}} \mathrm{R}$ ( $E_{\mathrm{GABA}}$, gray dashed), $\mathrm{HCO}_{3}{ }^{-}\left(E_{\mathrm{HCO}_{3}}\right.$, green) and chloride $\left(E_{\mathrm{Cl}^{-}}\right.$, blue); plus the extracellular $\mathrm{K}+$ concentration ([K+ $\mathrm{K}_{\text {out }}$, black). Insets (within dashed boxes) show transmembrane ion fluxes and gradients at two points during the response to $\mathrm{GABA}_{A} R$ activation. At the start of $\mathrm{GABA}_{A} R$ activation (left inset) $\left[\mathrm{Cl}^{-}\right]$is typically much higher outside neurons (e.g., $135 \mathrm{mM}$ ) as opposed to inside neurons (e.g., $6 \mathrm{mM}$ ). In contrast, $\left[\mathrm{HCO}_{3}{ }^{-}\right]$is only moderately higher outside $(23 \mathrm{mM})$ as compared to inside $(12 \mathrm{mM})$. Therefore at a typical resting membrane potential of $-60 \mathrm{mV}$, when $\mathrm{GABA}$ (red wedge) binds to ionotropic $\mathrm{GABA}_{\mathrm{A}} \mathrm{Rs}, \mathrm{Cl}^{-}$flows into the cell (blue arrow) while $\mathrm{HCO}_{3}^{-}$flows out (green arrow). As $\mathrm{GABA}_{A} \mathrm{Rs}$ are approximately four times more permeable to $\mathrm{Cl}^{-}$than to $\mathrm{HCO}_{3}^{-}$ions (Kaila and Voipio, 1987), the bulk of anion flux through the receptors is $\mathrm{Cl}^{-}$. This causes the membrane potential hyperpolarization typical of classic $G_{A B A} R$ mediated inhibition. With continued $\mathrm{GABA}_{A} \mathrm{R}$ activation (right inset), $\mathrm{Cl}^{-}$influx ultimately exceeds $\mathrm{Cl}^{-}$extrusion mechanisms and a reduction in the transmembrane $\mathrm{Cl}^{-}$gradient occurs (Staley and Proctor, 1999). A corresponding depletion of intracellular $\mathrm{HCO}_{3}^{-}$is prevented by the activity of carbonic anhydrase, which uses $\mathrm{CO}_{2}$ as a substrate to rapidly regenerate $\mathrm{HCO}_{3}^{-}$(Rivera et al., 2005). As a result, $E_{\mathrm{Cl}^{-}}$(blue trace) and hence $E_{\mathrm{GABA}}$ shift toward the more positive $E_{\mathrm{HCO}_{3}^{-}}$(green trace) causing the membrane depolarization typical of the biphasic GABAergic response. Intracellular $\mathrm{Cl}^{-}$ accumulation also results in the delayed extrusion of $\mathrm{K}^{+}$into the extracellular space via the $\mathrm{Cl}^{-} / \mathrm{K}^{+}$cotransporter $\mathrm{KCC} 2$. This further contributes to the late-stage depolarization of the biphasic response (Kaila et al., 1997; Viitanen et al., 2010).
$E_{\mathrm{GABA}}$ shifts. For example, one would expect that the greater the $\mathrm{Cl}^{-}$extruding capability of a neuron, the more resistant it would be to activity induced $\mathrm{Cl}^{-}$accumulation. Several mechanisms have been identified to play a role in $\mathrm{Cl}^{-}$efflux. These include $\mathrm{Cl}^{-}$ co-transporters such as $\mathrm{KCC} 2$ (Gamba, 2005), the $\mathrm{Cl}^{-} / \mathrm{HCO}_{3}^{-}$ exchanger (Sterling and Casey, 1999) and voltage-sensitive $\mathrm{Cl}^{-}$ channels (Rinke et al., 2010). Despite these multiple potential $\mathrm{Cl}^{-}$extruding pathways, electrophysiological experiments have shown that following a $\mathrm{Cl}^{-}$load, it is possible to fit the recovery of $\left[\mathrm{Cl}^{-}\right]_{\mathrm{i}}$ with a single exponent (Staley and Proctor, 1999; Raimondo et al., 2012a). This suggests that a single transporter, described by a single exponential process, is likely to play a dominant role in the recovery from $\mathrm{Cl}^{-}$accumulation. In most adult neurons, KCC2 has been identified as the major player in this process (Blaesse et al., 2009). As one would expect, reducing KCC2 activity within the context of a computational model (Doyon 
et al., 2011), or experimentally by genetic knockdown or pharmacological inhibition (Thompson and Gahwiler, 1989b; Jarolimek et al., 1999; Rivera et al., 2005; Zhu et al., 2005; Doyon et al., 2011), causes a depolarizing shift in resting $E_{\mathrm{GABA}}$. In addition, evidence suggests that reduced KCC2 activity hampers a neuron's ability to deal with an accumulation of intracellular $\mathrm{Cl}^{-}$and therefore slows the time to recover normal synaptic inhibition (Jin et al., 2005; Doyon et al., 2011). What may be underappreciated is that $\mathrm{KCC} 2$ has a limited $\mathrm{Cl}^{-}$affinity and transport capacity (Payne, 1997; Staley and Proctor, 1999; Song et al., 2002; Blaesse et al., 2009). This means that at a local level, and during the short time periods accompanying intense $\mathrm{GABA}_{\mathrm{A}} \mathrm{R}$ activation, the volume of the compartment into which $\mathrm{Cl}^{-}$flows and the rate of diffusion into other areas are also important parameters in governing the extent to which the $\mathrm{Cl}^{-}$concentration increases intracellularly (Staley and Proctor, 1999; Doyon et al., 2011).

Computational models (Qian and Sejnowski, 1990; Staley and Proctor, 1999; Doyon et al., 2011; Jedlicka et al., 2011) predict that for a given amount of synaptic $\mathrm{GABA}_{\mathrm{A}} \mathrm{R}$ activation and its accompanying $\mathrm{Cl}^{-}$influx, smaller post-synaptic volumes will result in relatively larger increases in $\left[\mathrm{Cl}^{-}\right]_{\mathrm{i}}$ and hence greater depolarizing shifts in $E_{\mathrm{GABA}}$. This explains the experimental finding that depolarizing responses to $\mathrm{GABA}_{\mathrm{A}} \mathrm{R}$ activation are more easily elicited over dendritic as opposed to somatic compartments (Figure 2 and Staley and Proctor, 1999). In a theoretical paper, Qian and Sejnowski (1990) employed this reasoning to suggest that $\mathrm{GABA}_{\mathrm{A}} \mathrm{R}$-mediated inhibition is likely to be ineffective on dendritic spines. Due to their minute volume, even small amounts of $\mathrm{Cl}^{-}$influx into a spine would be predicted to cause a local increase in $\left[\mathrm{Cl}^{-}\right]_{\mathrm{i}}$ that would rapidly depolarize $E_{\mathrm{GABA}}$. Consistent with this idea, it has since been confirmed that most GABAergic synapses are localized to dendritic shafts as opposed to spines (Freund and Buzsáki, 1996; Megías et al., 2001). In a similar vein, distal dendrites, apical tufts and the axon are also predicted to be prone to $\mathrm{Cl}^{-}$accumulation effects (Doyon et al., 2011). In addition to their small volume, the narrow diameter of these processes means that longitudinal diffusion of $\mathrm{Cl}^{-}$to other parts of the cell is severely restricted. This implies that multiple dendrite-targeting GABAergic inputs originating from a single pre-synaptic cell would have a larger inhibitory effect if the synapses are distributed throughout the dendritic tree, as opposed to being clustered along a single branch. Once again, such a morphological arrangement appears to be evident in different systems (Doyon et al., 2011; Jedlicka et al., 2011).

As well as the volume and rate of diffusion out of the intracellular compartment, another important factor that affects $\mathrm{Cl}^{-}$ accumulation during $\mathrm{GABA}_{\mathrm{A}} \mathrm{R}$ activity is the presence, affinity and capacity of carbonic anhydrase. For example, Staley et al. (1995) have shown that blocking carbonic anhydrase, the enzyme that maintains intracellular levels of $\mathrm{HCO}_{3}^{-}$, prevents a depolarizing response to strong $\mathrm{GABA}_{\mathrm{A}} \mathrm{R}$ activation. In addition, Ruusuvuori et al. (2004) demonstrated that it is the developmental up-regulation of carbonic anhydrase VII by the end of the second postnatal week that permits the emergence of biphasic GABAergic potentials in response to high frequency stimulation

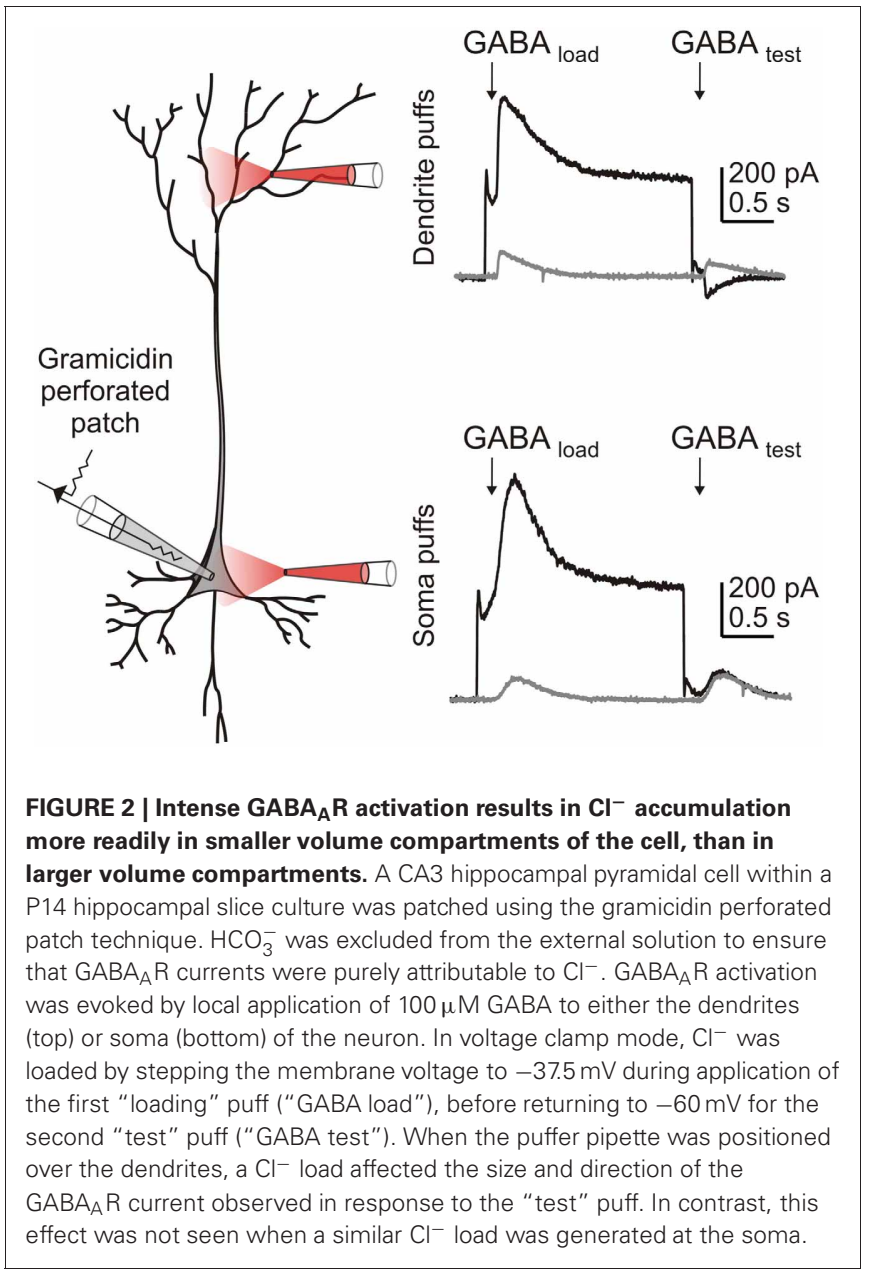

in rat hippocampus. $\mathrm{HCO}_{3}^{-}$ions therefore provide a pivotal link between neuronal regulation of $\mathrm{Cl}^{-}$and $\mathrm{pH}$ (Kaila et al., 1989, 1993; Doyon et al., 2011). For instance, although carbonic anhydrase activity is largely able to regenerate $\mathrm{HCO}_{3}^{-}$intracellularly in the face of $\mathrm{GABA}_{\mathrm{A}} \mathrm{R}$ induced $\mathrm{HCO}_{3}^{-}$efflux, the additional generation of intracellular hydrogen that accompanies intense activity (Schwiening et al., 1993; Wang et al., 1994; Xiong et al., 2000; Raimondo et al., 2012b) will shift the equilibrium set point of the carbonic anhydrase catalyzed reaction of $\mathrm{H}_{2} \mathrm{O}$ and $\mathrm{CO}_{2}$, to $\mathrm{HCO}_{3}^{-}$and $\mathrm{H}^{+}$. Therefore activity induced acidification is predicted to cause a reduction in the available intracellular $\mathrm{HCO}_{3}^{-}$and hence a hyperpolarization of $E_{\mathrm{HCO}_{3}^{-}}$. This would ultimately reduce the depolarization achievable by intense $\mathrm{GABA}_{\mathrm{A}} \mathrm{R}$ activation in the face of progressive intracellular acidification. For instance, an acidic shift of $0.2 \mathrm{pH}$ units would be predicted to generate a hyperpolarization of $E_{\mathrm{GABA}}$ on the order of $5 \mathrm{mV}$, although this remains to be verified experimentally (Kaila et al., 1990, 1993; Doyon et al., 2011). Finally, the membrane potential at which $\mathrm{GABA}_{\mathrm{A}} \mathrm{R}$ activation occurs will determine the driving force for $\mathrm{Cl}^{-}$influx. If GABAergic inputs occur synchronously with post-synaptic spiking or depolarizing glutamatergic EPSPs, this will increase the relative driving force for co-active $\mathrm{GABA}_{\mathrm{A}} \mathrm{Rs}$ and greatly facilitate $\mathrm{Cl}^{-}$accumulation 
and a positive shift in $E_{\mathrm{GABA}}$. Given the influence of the above mentioned parameters, it is perhaps not surprising that different cell types might differ in their susceptibility to $\mathrm{Cl}^{-}$accumulation. For example, Lamsa and Taira (2003) found that high frequency trains of stimulation generate depolarizing shifts in the $E_{\mathrm{GABA}}$ of hippocampal interneurons. However, corresponding stimulation did not elicit similar changes in $E_{\mathrm{GABA}}$ within $\mathrm{CA} 3$ pyramidal neurons.

In addition to cell type differences, the maturational state of a neuron is also likely to impact GABAergic ionic plasticity as $\mathrm{Cl}^{-}$homeostasis mechanisms are known to change during development. Compared to the $\mathrm{Cl}^{-}$extruder $\mathrm{KCC} 2$, immature neurons tend to express relatively high levels of the $\mathrm{Na}^{+}-\mathrm{K}^{+}-\mathrm{Cl}^{-}$ co-transporter, NKCC1, which imports $\mathrm{Cl}^{-}$into the cells. This means that $\left[\mathrm{Cl}^{-}\right]_{\mathrm{i}}$ is often significantly higher than in adult neurons (Ben-Ari, 2002). As a consequence, $E_{\mathrm{GABA}}$ is often depolarized relative to the resting membrane potential. Under these conditions it is predicted that repeated activation of $\mathrm{GABA}_{\mathrm{A}} \mathrm{Rs}$ would actually lead to a cumulative depletion of $\left[\mathrm{Cl}^{-}\right]_{\mathrm{i}}$, which would hyperpolarize $E_{\mathrm{GABA}}$ and reduce excitability in young tissue (Marchetti et al., 2005). Consistent with this, activitydependent depletion of $\left[\mathrm{Cl}^{-}\right]_{\mathrm{i}}$ has been demonstrated within the chick spinal cord and is implicated in the termination of spontaneous network events (Chub et al., 2006). In addition, repetitive intense $\mathrm{GABA}_{\mathrm{A}} \mathrm{R}$ activation via exogenous application of GABA or muscimol in young rodent cortex and hippocampus has been shown to deplete $\left[\mathrm{Cl}^{-}\right]_{\mathrm{i}}$ and hyperpolarize $E_{\mathrm{GABA}}$ (Brumback and Staley, 2008; Kolbaev et al., 2011). At a more general level, this work confirms that a cell's $\mathrm{Cl}^{-}$handling mechanisms have fundamental effects on the nature of ionic plasticity at GABAergic inputs.

Given the multiple factors that can influence short-term ionic plasticity at GABAergic synapses, it is important to consider how they might interact under different scenarios. For example, the axon initial segment (AIS) of pyramidal neurons is known to receive input almost exclusively from GABAergic axoaxonic cells. This subcellular compartment therefore offers an intriguing example of how the parameters described above might combine to generate $\left[\mathrm{Cl}^{-}\right]_{\mathrm{i}}$ accumulation or depletion effects. Firstly, the small volume of the AIS is predicted to amplify the effects of any $\mathrm{Cl}^{-}$flux on transmembrane concentration gradients. Secondly, the AIS has been shown to express the $\mathrm{Cl}^{-}$ importer NKCC1, instead of the $\mathrm{Cl}^{-}$extruder $\mathrm{KCC} 2$, which results in a relatively positive $E_{\mathrm{GABA}}$ at rest (Szabadics et al., 2006; Khirug et al., 2008; Woodruff et al., 2010). This compartment is therefore predicted to experience $\left[\mathrm{Cl}^{-}\right]_{\mathrm{i}}$ depletion in response to repeated GABAergic inputs at hyperpolarized membrane potentials. However, if GABAergic inputs were to arrive coincident with membrane potential depolarization, such as during action potential firing, rapid $\left[\mathrm{Cl}^{-}\right]_{\mathrm{i}}$ accumulation could still occur. As the AIS is the site of spike generation, dynamic, local changes to $E_{\mathrm{GABA}}$ could have a significant effect upon neuronal output. Future research is necessary to determine the existence and possible relevance of activity-dependent $\mathrm{Cl}^{-}$fluxes within the AIS.

To date, activity-dependent shifts in $E_{\mathrm{GABA}}$, have been demonstrated in response to intense $\mathrm{GABA}_{\mathrm{A}} \mathrm{R}$ activation, typically elicited either by exogenous application of $\mathrm{GABA}_{\mathrm{A}} \mathrm{R}$ agonists or high frequency stimulation of GABAergic afferents. Evidence that activity driven, short-term changes in $E_{\mathrm{GABA}}$ could occur in vivo have come from studies of hyper-active network activity states, such as those generated in experimental models of epilepsy. It is thought that the intense activation of $\mathrm{GABA}_{\mathrm{A}} \mathrm{Rs}$ in combination with the concurrent membrane depolarization that occurs during epileptiform activity can cause rapid $\mathrm{Cl}^{-}$accumulation (Lamsa and Kaila, 1997; Isomura et al., 2003; FujiwaraTsukamoto et al., 2010; Ilie et al., 2012). Indeed, the resultant erosion of $\mathrm{GABA}_{\mathrm{A}} \mathrm{R}$ mediated inhibition serves to initiate or exacerbate the hyperexcitability that is characteristic of epileptiform events (Lopantsev and Avoli, 1998; Lasztóczi et al., 2011; Ilie et al., 2012; Lillis et al., 2012). Beyond heightened network activity, it is currently an open question as to what sort of physiologically relevant activity patterns could lead to short-term changes to $E_{\mathrm{GABA}}$. Nonetheless, it is important to note that levels of $\left[\mathrm{Cl}^{-}\right]_{\mathrm{i}}$ accumulation appear to increase linearly with the intensity of $\mathrm{GABA}_{\mathrm{A}} \mathrm{R}$ activation. Even relatively weak stimulation can produce small changes in $\left[\mathrm{Cl}^{-}\right]_{\mathrm{i}}$ (Isomura et al., 2003; Berglund et al., 2006).

\section{FUNCTIONAL EFFECTS OF SHORT-TERM IONIC PLASTICITY AT GABAergic SYNAPSES}

What functional effects do short-term alterations in $E_{\mathrm{GABA}}$ have in the context of evolving pathological and physiological network activity? As described above, large depolarizing shifts in $E_{\mathrm{GABA}}$ have been shown to play a role in exacerbating and sustaining epileptic seizures. In addition, it has been observed that high frequency stimulation, of the sort used to induce classic longterm potentiation (LTP) at glutamatergic synapses, is sufficient to induce $\mathrm{GABA}_{\mathrm{A}} \mathrm{R}$ mediated depolarization (Thompson and Gahwiler, 1989a). This has led to the suggestion that one function of a short-term activity-dependent depolarizing shift in $E_{\mathrm{GABA}}$ is to modulate the $\mathrm{Mg}^{2+}$ block on NMDA receptors. This would suggest that the short-term GABAergic plasticity described above may play an important role in regulating NMDA-dependent mechanisms of synaptic plasticity (Staley et al., 1995).

By artificially setting the $E_{\mathrm{GABA}}$ of a neuron, one may investigate how physiologically plausible shifts in the ionic driving force for $\mathrm{GABA}_{\mathrm{A}}$ Rs may impact activity. This has been performed experimentally by dialyzing neurons during whole-cell recordings with internal solutions of set $\left[\mathrm{Cl}^{-}\right]_{\mathrm{i}}$, using dynamic clamp to simulate GABAergic inputs with different $E_{\mathrm{GABA}}$ values, or more recently using a light-activated $\mathrm{Cl}^{-}$pump to load neurons with different amounts of $\mathrm{Cl}^{-}$(Raimondo et al., 2012a). Studies performed in this manner have demonstrated that shifting $E_{\mathrm{GABA}}$ to moderately depolarizing values can result in enhanced spiking probability and reduced spike latencies in response to GABAergic inputs (Wang et al., 2001; Akerman and Cline, 2006; Saraga et al., 2008; Valeeva et al., 2010; Wright et al., 2011; Raimondo et al., 2012a). Computational models have also been used to study the impact that modest changes in $E_{\mathrm{GABA}}$ might have upon neural signaling. For instance, shifting the $E_{\mathrm{GABA}}$ in a model of a mature CA1 pyramidal neuron from $-75 \mathrm{mV}$ to $-70 \mathrm{mV}$ results in an increase in action potential firing frequency by approximately 40\% (Saraga et al., 2008). Similarly, depolarizing shifts 
in inhibitory reversal potentials by as little as $10 \mathrm{mV}$ can considerably shorten the duration of inhibitory inputs at the soma (Jean-Xavier et al., 2007). Small changes to $E_{\mathrm{GABA}}$ are more likely to be functionally significant when a fine balance exists between GABAergic inhibition and facilitation. For instance, in neocortical layer 5 neurons and dentate granule cells, $E_{\mathrm{GABA}}$ has been reported to lie at values more depolarized than the resting membrane potential, but below the action potential threshold (Kaila et al., 1993; Gulledge and Stuart, 2003; Chiang et al., 2012). This means that small changes in $E_{\mathrm{GABA}}$ could bidirectionally modulate neuronal firing rates and spike times (Morita et al., 2006; Chiang et al., 2012).

An intriguing possibility is that $\mathrm{Cl}^{-}$accumulation might adjust the processing capacity of a neuron's dendritic tree, and in a manner that depends upon the amount of information flowing through a particular network (Viitanen, 2010). The mechanism would operate as follows. If $E_{\mathrm{GABA}}$ is more negative than the resting membrane potential, then hyperpolarizing GABAergic inputs would spread further in time and space than their underlying conductances (Gulledge and Stuart, 2003). During periods of enhanced activity however, synaptic inputs to dendrites would be predicted to cause modest $\mathrm{Cl}^{-}$accumulation such that $E_{\mathrm{GABA}}$ moves toward the resting membrane potential, where GABAergic inputs will generate an exclusively shunting effect (Doyon et al., 2011; Jedlicka et al., 2011). Such a transition would serve to increase the spatial and temporal precision for integrating synaptic inputs, changing the fidelity of spike generation and effectively increasing the processing capacity of the dendritic compartment (London and Häusser, 2005; Viitanen, 2010). As such, shortterm GABAergic plasticity involving shifts in $E_{\mathrm{GABA}}$ could allow a neuron to adjust the information processing capacity of its dendritic tree "on the fly," to meet the varied computational demands of changing levels of neural activity. Given that interneurons are fundamental for the synchronization of neuronal networks (Whittington et al., 1995; Wang and Buzsáki, 1996), the activity dependent transition of inhibitory post-synaptic potentials from hyperpolarizing to shunting could also have important consequences for network oscillations. For instance, Vida et al. (2006), using a network model of interneurons, showed that shifting $E_{\mathrm{GABA}}$ from hyperpolarizing $(-75 \mathrm{mV})$ to shunting $(-55 \mathrm{mV})$ resulted in oscillations of markedly increased coherence and higher $\gamma$ band frequency. Even larger shifts in $E_{\mathrm{GABA}}$ however, ultimately result in a loss of synchrony (Jedlicka and Backus, 2006). Considering the role of gamma oscillations in spike timing dependent plasticity and sensory processing (Paulsen and Sejnowski, 2000; Engel and Singer, 2001; Buzsáki and Draguhn, 2004 ), it is conceivable that the dynamic modulation of $E_{\mathrm{GABA}}$ may have consequences for information coding and memory processes (Buzsaki, 2006; Mu and Poo, 2006; Richards et al., 2010).

An important question that can be asked about any plasticity phenomenon is one of synapse specificity. Does a plasticity process affect individual synapses between pre- and post-synaptic neurons, multiple surrounding synapses, or every connection to the post-synaptic cell in question? Considering that GABAergic interneurons are a highly heterogeneous cell population involved in a diverse array of functions, from setting network oscillations to providing dynamic gain control (Freund and Buzsáki, 1996; Gabernet et al., 2005), E $E_{\mathrm{GABA}}$ changes could be relevant over a range of spatial scales. At one extreme, one can consider whether $\mathrm{Cl}^{-}$accumulations could be sufficiently compartmentalized so as to remain specific to a single GABAergic synapse, akin to $\mathrm{Ca}^{2+}$ compartmentalization within a single dendritic spine (Bloodgood and Sabatini, 2007; Yuste, 2011). Földy et al. (2010) provide suggestive evidence that $\left[\mathrm{Cl}^{-}\right]_{\mathrm{i}}$ may be regulated on an input specific level. They show selective expression of the voltage gated $\mathrm{Cl}^{-}$channel, CLC2, at post-synaptic sites receiving input from parvalbumin-expressing basket cells (PVBCs), but not at post-synaptic sites receiving input from cholecystokininexpressing basket cells (CCKBCs). The presence of this inwardrectifying $\mathrm{Cl}^{-}$channel means that the synapses are able to extrude $\mathrm{Cl}^{-}$at a faster rate in the face of intense $\mathrm{GABA}_{\mathrm{A}} \mathrm{R}$ activation, whereas synapses without CLC2 show a greater propensity to exhibit shifts in $E_{\mathrm{GABA}}$. As Foldy et al. point out however, the somatodendritic distribution of PVBC and CCKBC synapses are somewhat different, which is likely to contribute to $E_{\mathrm{GABA}}$ differences (Földy et al., 2010). Nonetheless, this work demonstrates that ionic plasticity could be regulated according to synapse type, although the effects are not necessarily restricted to a single synapse. Indeed, modeling and experimental studies suggest that $\mathrm{Cl}^{-}$diffuses rapidly between synapses, with accumulations often only remaining localized at the level of a dendritic branch (Doyon et al., 2011; Jedlicka et al., 2011). This would suggest that activity dependent $\mathrm{Cl}^{-}$accumulations are likely to extend to surrounding synapses and therefore affect levels of inhibition in a spatially diffuse manner. Taken together, these studies highlight that future work is required to systematically explore the cell and synapse specific rules that influence short-term $E_{\mathrm{GABA}}$ changes.

\section{CONCLUSION}

Like the glutamatergic system, GABAergic synapses may undergo a wide array of both short- and long-term plasticity phenomena that rely on alterations in pre-synaptic release and/or postsynaptic receptor conductance. However, the GABAergic system is somewhat unique in that its function can also be relatively easily modified via changes to the ionic driving force for the $\mathrm{GABA}_{\mathrm{A}} \mathrm{R}$ and in a way that relates to the history of synaptic activity. It seems clear that $E_{\mathrm{GABA}}$ should not be assumed to be invariant across a neuron, it is a dynamic variable that evolves across both time and space as a function of varied patterns of neural activity. We anticipate that examining how this aspect of neuronal signaling contributes to network activity will provide fertile ground for future research.

\section{ACKNOWLEDGMENTS}

This work was supported by a grant from the Medical Research Council (G0601503) and funding from the European Research Council under the European Community's Seventh Framework Programme (FP7/2007-2013), ERC grant agreement number 243273. Joseph V. Raimondo was supported by a Rhodes Scholarship. We thank both reviewers for their constructive comments on the text and Kai Kaila for his suggestions for Figure 1. 


\section{REFERENCES}

Akerman, C. J., and Cline, H. T. (2006). Depolarizing GABAergic conductances regulate the balance of excitation to inhibition in the developing retinotectal circuit in vivo. J. Neurosci. 26, 5117-5130.

Alger, B., and Nicoll, R. (1979). GABAmediated biphasic inhibitory responses in hippocampus. Nature 281, 315-317.

Andersen, P., Dingledine, R., Gjerstad, L., Langmoen, I., and Laursen, A. M. (1980). Two different responses of hippocampal pyramidal cells to application of gamma-amino butyric acid. J. Physiol. 305, 279.

Ben-Ari, Y. (2002). Excitatory actions of GABA during development: the nature of the nurture. Nat. Rev. Neurosci. 3, 728-739.

Berglund, K., Schleich, W., Krieger, P., Loo, L. S., Wang, D., Cant, N. B., et al. (2006). Imaging synaptic inhibition in transgenic mice expressing the chloride indicator, Clomeleon. Brain Cell Biol. 35, 207-228.

Blaesse, P., Airaksinen, M. S., Rivera, C., and Kaila, K. (2009). Cationchloride cotransporters and neuronal function. Neuron $61,820-838$.

Bloodgood, B. L., and Sabatini, B. L. (2007). $\mathrm{Ca}(2+)$ signaling in dendritic spines. Curr. Opin. Neurobiol. 17, 345-351.

Brumback, A. C., and Staley, K. J. (2008). Thermodynamic regulation of NKCC1-mediated Cl-cotransport underlies plasticity of GABAA signaling in neonatal neurons. $J$. Neurosci. 28, 1301

Buzsaki, G. (2006). Rhythms of the Brain. New York, NY: Oxford University Press.

Buzsáki, G., and Draguhn, A. (2004). Neuronal oscillations in cortical networks. Science 304, 1926-1929.

Chiang, P.-H., Wu, P.-Y., Kuo, T.-W., Liu, Y.-C., Chan, C.-F., Chien, T.-C., et al. (2012). GABA is depolarizing in hippocampal dentate granule cells of the adolescent and adult rats. J. Neurosci. 32, 62-67.

Chub, N., Mentis, G. Z., and O'donovan, M. J. (2006). Chloridesensitive MEQ fluorescence in chick embryo motoneurons following manipulations of chloride and during spontaneous network activity. J. Neurophysiol. 95, 323-330.

Cohen, I., Navarro, V., Clemenceau, S., Baulac, M., and Miles, R. (2002). On the origin of interictal activity in human temporal lobe epilepsy in vitro. Science 298, 1418.

Davies, C. H., Davies, S. N., and Collingridge, G. L. (1990). Pairedpulse depression of monosynaptic
GABA-mediated inhibitory postsynaptic responses in rat hippocampus. J. Physiol. 424, 513-531.

Doyon, N., Prescott, S. A., Castonguay, A., Godin, A. G., Kröger, H., and De Koninck, Y. (2011). Efficacy of synaptic inhibition depends on multiple, dynamically interacting mechanisms implicated in chloride homeostasis. PLoS Comput. Biol. 7:e1002149. doi: 10.1371/journal.pcbi.1002149

Engel, A. K., and Singer, W. (2001) Temporal binding and the neural correlates of sensory awareness. Trends. Cogn. Sci. 5, 16-25.

Farrant, M., and Kaila, K. (2007). The cellular, molecular and ionic basis of GABAA receptor signalling. Prog. Brain Res. 160, 59-87.

Fiumelli, H., Cancedda, L., and Poo, M.-M. (2005). Modulation of GABAergic transmission by activity via postsynaptic $\mathrm{Ca} 2+$-dependent regulation of KCC2 function. Neuron 48, 773-786.

Fleidervish, I. A., and Gutnick, M. J. (1995). Paired-pulse facilitation of IPSCs in slices of immature and mature mouse somatosensory neocortex. J. Neurophysiol. 73, 2591-2595.

Földy, C., Lee, S.-H., Morgan, R. J., and Soltesz, I. (2010). Regulation of fast-spiking basket cell synapses by the chloride channel ClC-2. Nat. Neurosci. 13, 1047-1049.

Freund, T. F., and Buzsáki, G. (1996). Interneurons of the hippocampus. Hippocampus 6, 347-470.

Fujiwara-Tsukamoto, Y., Isomura, Y., Imanishi, M., Ninomiya, T., Tsukada, M., Yanagawa, Y., et al. (2010). Prototypic seizure activity driven by mature hippocampal fastspiking interneurons. J. Neurosci. 30, 13679 .

Gabernet, L., Jadhav, S. P., Feldman, D. E., Carandini, M., and Scanziani, M. (2005). Somatosensory integration controlled by dynamic thalamocortical feed-forward inhibition. Neuron 48, 315-327.

Gaiarsa, J.-L., Caillard, O., and BenAri, Y. (2002). Long-term plasticity at GABAergic and glycinergic synapses: mechanisms and functional significance. Trends Neurosci. 25, 564-570.

Gamba, G. (2005). Molecular physiology and pathophysiology of electroneutral cation-chloride cotransporters. Physiol. Rev. 85, 423-493.

Gulledge, A. T., and Stuart, G. J. (2003). Excitatory actions of GABA in the cortex. Neuron 37, 299-309.

Gupta, A., Wang, Y., and Markram, H. (2000). Organizing principles for a diversity of GABAergic interneurons and synapses in the neocortex. Science 287, 273-278.

Huguenard, J. R., and Alger, B. E. (1986). Whole-cell voltage-clamp study of the fading of GABAactivated currents in acutely dissociated hippocampal neurons. $J$. Neurophysiol. 56, 1-18.

Ilie, A., Raimondo, J. V., and Akerman, C. J. (2012). Adenosine release during seizures attenuates GABAA receptor-mediated depolarization. J. Neurosci. 32, 5321-5332.

Isomura, Y., Sugimoto, M., FujiwaraTsukamoto, Y., Yamamoto-Muraki, S., Yamada, J., and Fukuda, A (2003). Synaptically activated Cl- accumulation responsible for depolarizing GABAergic responses in mature hippocampal neurons. J. Neurophysiol. 90, 2752-2756.

Jarolimek, W., Lewen, A., and Misgeld U. (1999). A furosemide-sensitive $\mathrm{K}+-\mathrm{Cl}$ - cotransporter counteracts intracellular Cl- accumulation and depletion in cultured rat midbrain neurons. J. Neurosci. 19 4695-4704.

Jean-Xavier, C., Mentis, G. Z., O'Donovan, M. J., Cattaert, D. and Vinay, L. (2007). Dual personality of GABA/glycine-mediated depolarizations in immature spinal cord. Proc. Natl. Acad. Sci. U.S.A 104, 11477-11482.

Jedlicka, P., and Backus, K. H. (2006). Inhibitory transmission, activitydependent ionic changes and neuronal network oscillations. Physiol. Res. 55, 139-149.

Jedlicka, P., Deller, T., and Gutkin, B (2011). Activity dependent intracellular chloride accumulation and diffusion controls GABAA receptor mediated synaptic transmission. Hippocampus 898, 885-898.

Jiang, L., Sun, S., Nedergaard, M., and Kang, J. (2000). Paired-pulse modulation at individual GABAergic synapses in rat hippocampus. J. Neurophysiol. 523( $\mathrm{Pt} 2)$, 425-439.

Jin, X., Huguenard, J. R., and Prince, D. A. (2005). Impaired Cl-extrusion in layer $\mathrm{V}$ pyramidal neurons of chronically injured epileptogenic neocortex. J. Neurophysiol. 93, 2117.

Kaila, K. (1994). Ionic basis of GABAA receptor channel function in the nervous system. Prog. Neurobiol. 42, 489.

Kaila, K., Lamsa, K., Smirnov, S., Taira, T., and Voipio, J. (1997). Longlasting GABA-mediated depolarization evoked by high-frequency stimulation in pyramidal neurons of rat hippocampal slice is attributable to a network-driven, bicarbonatedependent $\mathrm{K}+$ transient. J. Neurosci. 17, 7662.

Kaila, K., Pasternack, M., Saarikoski, J., and Voipio, J. (1989). Influence of GABA-gated bicarbonate conductance on potential, current and intracellular chloride in crayfish muscle fibres. J. Physiol. 416, 161-181.

Kaila, K., Saarikoski, J., and Voipio, J. (1990). Mechanism of action of GABA on intracellular $\mathrm{pH}$ and on surface $\mathrm{pH}$ in crayfish muscle fibres. J. Physiol. 427, 241-260.

Kaila, K., and Voipio, J. (1987). Postsynaptic fall in intracellular $\mathrm{pH}$ induced by GABA-activated bicarbonate conductance. Nature 330, 163-165.

Kaila, K., Voipio, J., Paalasmaa, P., Pasternack, M., and Deisz, R. A. (1993). The role of bicarbonate in GABAA receptor-mediated IPSPs of rat neocortical neurones. J. Physiol. 464, 273-289.

Khirug, S., Yamada, J., Afzalov, R. Voipio, J., Khiroug, L., and Kaila, K. (2008). GABAergic depolarization of the axon initial segment in cortical principal neurons is caused by the $\mathrm{Na}-\mathrm{K}-2 \mathrm{Cl}$ cotransporter NKCC1. J. Neurosci. 28, 4635-4639.

Kirischuk, S., Clements, J. D., and Grantyn, R. (2002). Presynaptic and postsynaptic mechanisms underlie paired pulse depression at single GABAergic boutons in rat collicular cultures. J. Physiol. 543, 99-116.

Kolbaev, S. N., Luhmann, H. J., and Kilb, W. (2011). Activity-dependent scaling of GABAergic excitation by dynamic Cl- changes in CajalRetzius cells. Eur. J. Neurosci. 461, 557-565.

Kuner, T., and Augustine, G. J. (2000). A genetically encoded ratiometric indicator for chloride: capturing chloride transients in cultured hippocampal neurons. Neuron 27, 447-459.

Lambert, N., and Grover, L. (1995). The mechanism of biphasic GABA responses. Science 269, 928-929.

Lambert, N., and Wilson, W. (1994). Temporally distinct mechanisms of use-dependent depression at inhibitory synapses in the rat hippocampus in vitro. J. Neurophysiol. 72, 121-130.

Lamsa, K. P., and Kaila, K. (1997). Ionic mechanisms of spontaneous GABAergic events in rat hippocampal slices exposed to 4-aminopyridine. J. Neurophysiol. $78,2582$.

Lamsa, K. P., Kullmann, D. M., and Woodin, M. A. (2010). Spike-timing 
dependent plasticity in inhibitory circuits. Front. Synaptic Neurosci. 2:8. doi: 10.3389/fnsyn.2010.00008

Lamsa, K. P., and Taira, T. (2003). Usedependent shift from inhibitory to excitatory GABAA receptor action in SP-O interneurons in the rat hippocampal CA3 area. J. Neurophysiol. 90, 1983.

Lasztóczi, B., Nyitrai, G., Héja, L., and Kardos, J. (2011). Synchronization of GABAergic inputs to CA3 pyramidal cells precedes seizure-like event onset injuvenile rat hippocampal slices. J. Neurophysiol. 102, 2538-2553.

Lillis, K. P., Kramer, M. A., Mertz, J., Staley, K. J., and White, J. A. (2012). Pyramidal cells accumulate chloride at seizure onset. Neurobiol. Dis. 47, 358-366.

London, M., and Häusser, M. (2005). Dendritic computation. Annu. Rev. Neurosci. 28, 503-532.

Lopantsev, V., and Avoli, M. (1998). Participation of GABAA-mediated inhibition in ictallike discharges in the rat entorhinal cortex. J. Neurophysiol. 79, 352.

Marchetti, C., Tabak, J., Chub, N., O'Donovan, M. J., and Rinzel, J. (2005). Modeling spontaneous activity in the developing spinal cord using activity-dependent variations of intracellular chloride. J. Neurosci. 25, 3601-3612.

McCarren, M., and Alger, B. E. (1985). Use-dependent depression of IPSPs in rat hippocampal pyramidal cells in vitro. J. Neurophysiol. 53, 557-571.

Megías, M., Emri, Z., Freund, T.., and Gulyas, A. (2001). Total number and distribution of inhibitory and excitatory synapses on hippocampal CA1 pyramidal cells. Neuroscience 102, 527-540.

Morita, K., Tsumoto, K., and Aihara, K. (2006). Bidirectional modulation of neuronal responses by depolarizing GABAergic inputs. Biophys. J. 90, 1925-1938.

Mott, D. D., Xie, C. W., Wilson, W. A., Swartzwelder, H. S., and Lewis, D. V. (1993). GABAB autoreceptors mediate activitydependent disinhibition and enhance signal transmission in the dentate gyrus. J. Neurophysiol. 69, 674-691.

Mu, Y., and Poo, M.-M. (2006). Spike timing-dependent LTP/LTD mediates visual experiencedependent plasticity in a developing retinotectal system. Neuron 50, 115-125.

Overstreet, L. S., Jones, M. V., and Westbrook, G. L. (2000).
Slow desensitization regulates the availability of synaptic GABAA receptors. J. Neurosci. 20, 7914-7921.

Pathak, H. R., Weissinger, F., Terunuma, M., Carlson, G. C., Hsu, F. C., Moss, S. J., et al. (2007). Disrupted dentate granule cell chloride regulation enhances synaptic excitability during development of temporal lobe epilepsy. J. Neurosci. 27, 14012 .

Paulsen, O., and Sejnowski, T. J. (2000). Natural patterns of activity and long-term synaptic plasticity. Curr. Opin. Neurobiol. 10, 172-179.

Payne, J. A. (1997). Functional characterization of the neuronalspecific $\mathrm{K}-\mathrm{Cl}$ cotransporter: implications for $\left[\mathrm{K}^{+}\right]_{\mathrm{o}}$ regulation. Am. J. Physiol. 273(5 Pt 1), C1516-C1525.

Perkins, K. L. (1999). Cl- accumulation does not account for the depolarizing phase of the synaptic GABA response in hippocampal pyramidal cells. J. Neurophysiol. 82, 768-777.

Perkins, K. L., and Wong, R. K. S. (1997). The depolarizing GABA response. Can. J. Physiol. Pharmacol. 75, 515-519.

Pouille, F., and Scanziani, M. (2004). Routing of spike series by dynamic circuits in the hippocampus. Nature 429, 717-723.

Qian, N., and Sejnowski, T. J. (1990). When is an inhibitory synapse effective? Proc. Natl. Acad. Sci. U.S.A. 87, 8145-8149.

Raimondo, J. V., Kay, L., Ellender, T. J., and Akerman, C. J. (2012a). Optogenetic silencing strategies differ in their effects on inhibitory synaptic transmission. Nat. Neurosci. 15, 1102-1104.

Raimondo, J. V., Irkle, A., Wefelmeyer, W., Newey, S. E., and Akerman, C. J. (2012b). Genetically encoded proton sensors reveal activitydependent $\mathrm{pH}$ changes in neurons. Front. Mol. Neurosci. 5:68. doi: 10.3389/fnmol.2012.00068

Richards, B. A., Voss, O. P., and Akerman, C. J. (2010). GABAergic circuits control stimulus-instructed receptive field development in the optic tectum. Nat. Neurosci. 13, 1098-1106.

Rinke, I., Artmann, J., and Stein, V. (2010). ClC-2 voltage-gated channels constitute part of the background conductance and assist chloride extrusion. J. Neurosci. 30, 4776-4786.

Rivera, C., Voipio, J., and Kaila, K. (2005). Two developmental switches in GABAergic signalling: the $\mathrm{K}+-$ Cl- cotransporter KCC2 and carbonic anhydrase CAVII. J. Physiol. 562, 27.

Ruusuvuori, E., Li, H., Huttu, K., Palva, J. M., Smirnov, S., Rivera, C., et al. (2004). Carbonic anhydrase isoform VII acts as a molecular switch in the development of synchronous gamma-frequency firing of hippocampal CA1 pyramidal cells. J. Neurosci. 24, 2699.

Saraga, F., Balena, T., Wolansky, T., Dickson, C. T., and Woodin, M. A. (2008). Inhibitory synaptic plasticity regulates pyramidal neuron spiking in the rodent hippocampus. Neuroscience 155, 64-75.

Schwiening, C. J., Kennedy, H. J., and Thomas, R. C. (1993). Calciumhydrogen exchange by the plasma membrane Ca-ATPase of voltageclamped snail neurons. Proc. Biol. Sci. 253, 285-289.

Smirnov, S., Paalasmaa, P., Uusisaari, M., Voipio, J., and Kaila, K. (1999). Pharmacological isolation of the synaptic and nonsynaptic components of the GABA-mediated biphasic response in rat CA1 hippocampal pyramidal cells. $J$. Neurosci.19, 9252-9260.

Song, L., Mercado, A., Vázquez, N., Xie, Q., Desai, R., George, A. L., et al. (2002). Molecular, functional, and genomic characterization of human $\mathrm{KCC} 2$, the neuronal K-Cl cotransporter. Brain Res. Mol. Brain Res. 103, 91-105.

Staley, K. J., and Proctor, W. R. (1999). Modulation of mammalian dendritic GABAA receptor function by the kinetics of $\mathrm{Cl}-$ and $\mathrm{HCO}_{3}-$ transport. J. Physiol. 519, 693.

Staley, K., Soldo, B., and Proctor, B. L. (1995). Ionic mechanisms of neuronal excitation by inhibitory GABAA receptors. Science. 269, 977-981.

Sterling, D., and Casey, J. R. (1999). Transport activity of AE3 chloride/bicarbonate anion-exchange proteins and their regulation by intracellular pH. Biochem. J. 229, 221-229.

Szabadics, J., Varga, C., Molnar, G., Olah, S., Barzo, P., and Tamas, G. (2006). Excitatory effect of GABAergic axo-axonic cells in cortical microcircuits. Science 311, 233-235.

Thompson, S. M., and Gahwiler, B. H. (1989a). Activity-dependent disinhibition. II. Effects of extracellular potassium, furosemide, and membrane potential on ECl-in hippocampal CA3 neurons. J. Neurophysiol. 61, 512.
Thompson, S., and Gahwiler, B. (1989b). Activity-dependent disinhibition. I. Repetitive stimulation reduces IPSP driving force and conductance in the hippocampus in vitro. J. Neurophysiol. 61, 501.

Tsodyks, M. V., and Markram, H. (1997). The neural code between neocortical pyramidal neurons depends. Proc. Natl. Acad. Sci. U.S.A. 94, 719-723.

Valeeva, G., Abdullin, A., Tyzio, R., Skorinkin, A., Nikolski, E., BenAri, Y., et al. (2010). Temporal coding at the immature depolarizing GABAergic synapse. Front. Cell. Neurosci. 4:17. doi: 10.3389/fncel.2010.00017

Varela, J., Sen, K., Gibson, J., Fost, J., Abbott, L. F., and Nelson, S. B. (1997). A quantitative description of short-term plasticity at excitatory synapses in layer $2 / 3$ of rat primary visual cortex. J. Neurosci. 17, 7926-7940.

Vida, I., Bartos, M., and Jonas, P. (2006). Shunting inhibition improves robustness of gamma oscillations in hippocampal interneuron networks by homogenizing firing rates. Neuron 49, 107-117.

Viitanen, T. (2010). GABA $\mathrm{A}$ Receptor Mediated Signalling in the Brain: Inhibition, Shunting and Excitation. Phd Thesis. University of Helsinki, Finland, ISBN: 978-952-10-6364-0.

Viitanen, T., Ruusuvuori, E., Kaila, K., and Voipio, J. (2010). The K+$\mathrm{Cl}$ cotransporter KCC2 promotes GABAergic excitation in the mature rat hippocampus. J. Physiol. 588, 1527-1540.

Voipio, J., and Kaila, K. (2000). GABAergic excitation and $\mathrm{K}+$ mediated volume transmission in the hippocampus. Prog. Brain Res. 125, 329-338.

Wang, G. J., Randall, R. D., and Thayer, S. A. (1994). Glutamateinduced intracellular acidification of cultured hippocampal neurons demonstrates altered energy metabolism resulting from $\mathrm{Ca}^{2+}$ loads. J. Neurophysiol. 72, 2563-2569.

Wang, X. J., and Buzsáki, G. (1996). Gamma oscillation by synaptic inhibition in a hippocampal interneuronal network model. J. Neurosci. 16, 6402-6413.

Wang, Y., Gao, X., and van den Pol, A. (2001). Membrane properties underlying patterns of GABAdependent action potentials in developing mouse hypothalamic neurons. J. Neurophysiol. 86, 1252-1265. 
Whittington, M. A., Traub, R. D., and Jefferys, J. G. R. (1995). Synchronized oscillations in interneuron networks driven by metabotropic glutamate receptor activation. Nature 373, 612-615.

Woodin, M. A., Ganguly, K., and Poo, M. (2003). Coincident preand postsynaptic activity modifies GABAergic synapses by postsynaptic changes in Cl-transporter activity. Neuron 39, 807-820.

Woodruff, A. R., Anderson, S. A., and Yuste, R. (2010). The enigmatic function of chandelier cells. Front. Neurosci. 4:201. doi: $10.3389 /$ fnins.2010.00201
Wright, R., Raimondo, J. V., and Akerman, C. J. (2011). Spatial and temporal dynamics in the ionic driving force for $\operatorname{GABA}(\mathrm{A})$ receptors. Neural Plast. 2011, 728395.

Xiong, Z. Q., Saggau, P., and Stringer, J. L. (2000). Activity-dependent intracellular acidification correlates with the duration of seizure activity. J. Neurosci. 20, 1290.

Yuste, R. (2011). Dendritic spines and distributed circuits. Neuron 71, 772-781.

Zhu, L., Lovinger, D., and Delpire, E. (2005). Cortical neurons lacking KCC2 expression show impaired regulation of intracellular chloride. J. Neurophysiol. 93, 1557-1568.

Zucker, R. S., and Regehr, W. G. (2002). Short-term synaptic plasticity. Ann. Rev. Physiol. 64, 355-405.

Conflict of Interest Statement: The authors declare that the research was conducted in the absence of any commercial or financial relationships that could be construed as a potential conflict of interest.

Received: 28 June 2012; paper pending published: 07 July 2012; accepted:
28 September 2012; published online: 16 October 2012.

Citation: Raimondo JV, Markram H and Akerman CJ (2012) Short-term ionic plasticity at GABAergic synapses. Front. Syn. Neurosci. 4:5. doi: 10.3389/fnsyn. 2012.00005

Copyright (c) 2012 Raimondo, Markram and Akerman. This is an open-access article distributed under the terms of the Creative Commons Attribution License, which permits use, distribution and reproduction in other forums, provided the original authors and source are credited and subject to any copyright notices concerning any third-party graphics etc. 